

\title{
Egzersiz Fizyolojisi Bağlamında Musküler Plastisite
}

\author{
Burak KARIP ${ }^{1}$ \\ Hüseyin Avni BALCIOĞLU ${ }^{*}$ (D) \\ ${ }^{1}$ Sağlık Bilimleri Üniversitesi, Hamidiye Tıp Fakültesi, ISTANBUL
}

Derleme / Review

Geliş Tarihi / Received: 30.06.2021 Kabul Tarihi / Accepted: 12.08.2021

Yayın Tarihi / Published: 20.09.2021

\begin{abstract}
Öz
İskelet kaslarının yaşa, egzersiz çeşidine ve bazı hastalıklara verdiği makro ve moleküler düzeydeki tepki ve adaptasyonlar plastisiteye etki eden en önemli faktörlerdir. Egzersiz fizyolojisi temelinde sahip olduğu anlamla birlikte, sarkopeni gibi iskelet kası bozuklukları; travmaya bağlı ya da deneysel modellemelerle oluşan medulla spinalis yaralanmaları; çeşitli dayanıklıık, güç ve kuvvet antrenmanlarıyla ilgili kas liflerinde bulunan miyozin ağır zincirlerinde meydana gelen değişikliklerde musküler plastisite mekanizmaları giderek artan sayıda klinik ve translasyonel çalışmanın konusu olmaktadır. Buna binaen, Tip I, Tip Ila ve Tip IIx kas lifi tiplerinin fizyolojik, yapısal ve biyokimyasal özellikleri insanda iskelet kası plastisitesine etki eden en önemli faktörlerdir. Antrenman çeşitlerinin kaslara etkisi mitokondriyel değişiklikler, Ca++ oranları ve genetik faktörler ile yakından ilişkilidir. Özellikle bu faktörlere bağlı oluşan sonuçlara göre, kişiye özel düzenlenen antrenman çeşitleri ve içerikleri, günümüzde egzersiz fizyolojisinin önceliklerindendir. Bu konuda yapılan deneylerin büyük çoğunluğu inme modellemeleri ve $\mathrm{m}$. soleus, $\mathrm{m}$. tibialis anterior gibi kasların kas-sinir ilişkisine bağlı fenotip incelemeleriyle ilgili çalışmalardır. Bu derlemede, iskelet kaslarındaki plastisiteye bağlı değişikliklerin, çeşitli faktörlerle olan ilişkilerinin incelenmesi ve özellikle egzersiz çeşitleri ile bağlantılarının ortaya koyulması hedeflendi.
\end{abstract}

Anahtar Kelimeler: Musküler Plastisite; İskelet Kası; Egzersiz Fizyolojisi

\section{Muscular Plasticity in Terms of Exercise Physiology}

\begin{abstract}
The reactions and adaptations of the skeletal muscles at macro and molecular levels to aging, work-out types and some diseases are major factors in plasticity. Together with its significance in exercise physiology, the mechanisms of the muscular plasticity in skeletal muscle diseases such as sarcopenia, trauma or experimental models of spinal cord injuries, alterations in the myosin heavy chains of the muscular fibers due to the strength and power work-outs are subject of more and more clinical and translational studies. Accordingly, the physiological, structural and biochemical properties of the muscle fibers type I, typella ve type IIx are of utmost vitality affecting the skeletal muscle plasticity. The effects of the work-out types on muscles are in close relationship with the mitochondrial variations, $\mathrm{Ca}++$ rates and genetic factors. Regarding the results according to these factors particularly, personalized work-out types and the contents have priorities in terms of exercise physiology. Most of the experiments deal with stroke models and phenotype investigations of the muscles such as soleus and tibialis anterior, in terms of muscle-nerve relation. This review aims to investigate the relations of the alterations due to the skeletal muscle plasticity with various factors and to evaluate its connections particularly with the work-out types.
\end{abstract}

Keywords: Muscular Plasticity; Skeletal muscle; Exercise Physiology

\footnotetext{
* Sorumlu Yazar: Hüseyin Avni BALCIOĞLU
}

e-mail: h.avni@sbu.edu.tr 
Karip, B., ve Balcığlu, H.A. (2021). Egzersiz Fizyolojisi Bağlamında Musküler Plastisite. Gaziantep Üniversitesi Spor Bilimleri Dergisi, 6(3), 266-278.

\section{Giriş}

İskelet kaslarına ait yapılar çevre koşullarının değişimine cevap verebilmek için adaptif potansiyele sahiptir. Aktivite artması veya azalmasına bağlı olarak, kaslarda meydana gelen birçok adaptasyon anlaşılmasına rağmen, bunları desteklemek ya da önlemek için en iyi yolun nasıl olduğuna dair bir konsensus yoktur. Bunun sebeplerinden en güçlü olanı ise, kas yapılarının egzersizlere verdiği bireysel tepkilerin her kişide farklı oluşudur (Bruton, 2002). Kas fenotipi paradigmalarındaki değişikliklerin saptanabilmesi için kediler üzerinde oluşturulan bir çalışma modelinde, yavaş kasılan m. soleus'un, normalde daha hızı kasılan m.flexor digitorum longus kasının kasılma hızının artmasını sağlayan sinir lifleri tarafından yeniden uyarıldığında hızlı kasılmaya başladığını ve hızlı kasılan m. flexor digitorum longus'un ise $\mathrm{m}$. soleus'u inerve eden sinir ile yeniden uyarıldığında daha yavaş kasılmaya başladığı gösterdi. Bu sonuçlar, motor sinirlerin, inerve ettikleri kasların fenotipleri üzerinde bir etki oluşturduğunu ortaya çıkardı (Dirk Pette, 2001). Kas liflerinin bu şekillendirilebilirliği, bu deneyler hakkındaki ilk raporun başlığında "plastisite" terimini olarak kullanmasına ilham verdi (Eccles, 1958).

\section{İskelet kaslarının yapısal özellikleri}

İskelet kaslarında lifler, çoğu zaman kasın tüm seyri boyunca uzanırlar ve genellikle inervasyonları bir tek sinir tarafından sağlanır (Hall ve Hall, 2020). Miyoflamentlerin oluşturduğu miyofibriller, kas liflerini oluşturmaktadır. Lifler, fasiküller ve kaslar bağ dokusunun matriksi ile çevrelenir. Bu bağ dokuları, belirli bir geometrik düzende lifleri sararak kası kemiğe bağlayan bir iskele görevi görmektedir (Lieber ve ark., 2017). Kas lifleri endomysium ile sarılı fasikülleri oluşturduğunda, bu fasiküller etrafındaki perimysium ve devamında tümünü saran epimysium tabakasıyla kasın temel mimarisini tamamlar. Miyofilamentler; kalın filamentler miyozin, ince filamentler aktin olarak bilinirler (Standring, 2015).

Polarize ışığa izotropik olan açık bantlar (I bandı) aktin, tersine anizotropik olan koyu bantlar (A bandı) ise miyozin miyofilamentlerini göstermektedir. Çeşitli filamentöz yapıların oluşturduğu Z diski, aktinlerin tutunduğu yapılardır. Her iki Z çizgisi arası sarkomer olarak isimlendirilir ve sarkomerlerin tam gerginlikteki boyu yaklaşık $2 \mu$ m'dir (Hall ve Hall, 2020). Aktin'i troponin kompleksine bağlayan her tropomiyozin molekülü yaklaşık 7 aktin monomeri boyunca uzanır. Troponin çeşitleri ise afinitelerine göre şu şekilde sıranlanmıştır: troponin I - aktin, troponin $\mathrm{T}$ - 
Karip, B., ve Balcıoğlu, H.A. (2021). Egzersiz Fizyolojisi Bağlamında Musküler Plastisite. Gaziantep Üniversitesi Spor Bilimleri Dergisi, 6(3), 266-278.

tropomiyozin ve troponin C - Ca++ (Standring, 2015). Her bir troponin C'ye yaklaşık 4 adet $\mathrm{Ca++}$ bağlanabilir. Diğer yandan her birine bir ADP molekülü tutunan polimerize G-aktin, çift sarmal yapıdaki F-aktin'i oluşturmaktadır. Bu yapının kas kasılması sırasında, miyozin filamentleri ile etkileşime girilen aktif bölgeler olduğu düşünülmektedir (Hall ve Hall, 2020).

$\mathrm{Bu}$ bilgiler rehberliğinde genel olarak kas kasılması şu şekilde özetlenebilir; aksiyon potansiyelinin hareketi, sinaptik aralığa sinir uçlarından salgılanan asetilkolin gideceği yere ulaşana kadar devam eder ve lokal bir alanda etki göstererek kanalları açmasıyla, sodyum iyonlarının içeriye girişi aksiyon potansiyelinin kas liflerinde de başlamasına sebep olur. Kas lifi membranında yayılan bu etki, depolarizasyonla birlikte $\mathrm{Ca++}$ iyonlarının miyofibrillere doğru hareket etmesini sağlar. Serbestlenen Ca++ iyonları ise troponin C ile bağlantı kurarak, aktin ve miyozin miyofilamentleri arasındaki etkileşimi başlatır (Vickers, Nair, Wheeldon, Peate ve Migliozzi). Hücre içi $\mathrm{Ca}++$, iskelet kası uyarımı- kasılma bağlantısında ve ayrıca uyarma-transkripsiyon bağlantısında önemli rol oynar (Chin, 2004).

\section{Musküler plastisite}

İskelet kası fenotipi önemli ölçüde şekillendirilebilirliğe sahiptir (Hans Hoppeler, 2016). Buna örnek olarak; kalın filamentleri $Z$ diskine bağlayan titin moleküllerinin elastik bölgeleri I bandındadır. Bu sayede kas lifi gerilmeye karşı pasif bir dirence ve elastik geri tepme özelliğine sahip olur (Standring, 2015). İskelet kasının tüm türlerde yüksek seviyede esnek bir doku olduğu gösterilmiştir. Kas dokusunun yapısal değişikliklerinin altında yatan moleküler mekanizmaların çoğu bu yüzyılda çözülmüştür (Hans Hoppeler, 2016). Çeşitli hastalıklardan günümüze değin elde edilen tecrübe ve bilgi toplamı, sağlıklı ve hastalık sahibi bireylerde iskelet kası plastisitesine ilişkin anlayışın geliştirilmesi gerektiğini ortaya koymaktadır. Örneğin; gelinen noktada, birçok birey multiple skleroz gibi zayıflatıcı bir hastalıkla uzun süre yaşayabiliyor veya sadece daha uzun bir yaşam süresine sahip olabiliyor (Baldwin, 2000).

Fiziksel egzersiz, morfolojik ve metabolik değişiklikleri harekete geçirmek için hücresel sinyal mekanizmalarını büyük ölçüde düzenleyebilen bir stres çeşididir. İskelet kası proteini ve hücre organellerinin döngüsü iki büyük hücresel yola bağlıdır: Forkhead box class $O$ protein (FOXO) transkripsiyon faktörleri ve protein translasyonu ve otofaji inhibisyonu ile ilişkili mTORC1 sinyali (mammalian target of 
Karip, B., ve Balcıŏlu, H.A. (2021). Egzersiz Fizyolojisi Bağlamında Musküler Plastisite. Gaziantep Üniversitesi Spor Bilimleri Dergisi, 6(3), 266-278.

rapamycin complex 1 or mechanistic target of rapamycin complex 1) (Sanchez ve ark., 2014). Son yıllarda akut ve kronik dayanıklılık egzersizlerinin otofaji yolağını etkileyebildiği gösterilmiştir. Dayanıklılık antrenmanlarının mitokondriyal hareketliliği artırdığı iyi bilinmektedir, bu da oksidatif fenotip ve kas dayanıklılığında kas büyüklüğü üzerinde minimal bir etki ile sonuçlanır (Bishop ve ark., 2014). Bununla birlikte, güç ve direnç antrenmanları kas hipertrofisi ile yakından ilişkilidir (Tesch, 1988).

\section{Musküler plastisite ve mikroflament ilişkisi}

Miyozin 2 ağır (MHC) ve 2 hafif (MLC) zincirden oluşur. Rat iskelet kaslarında 4 farklı MHC bulunur; MHC-1, MHC-2a, MHC-2x ve MHC-2b. Kas lifi tipleri de bu isoformlara göre tanımlanır; tip I, tip Ila, tipllx ve tip IIb. Ratların aksine insanda 3 adet miyozin ağır zincir izoformu ve kas lifi tipi vardır; MHC-1, MHC-2a ve MHC-2x I tip I, tiplla ve tip IIx (b) (Bruton, 2002). MHC- Kas lifi tipi eşleştirmelerine göre var olan özelliklerin şu şekildedir: MHC-1/ tip I; yavaş kasılan-oksidatif enzim aktivitesine sahip, kasılma hızı yavaş, kırmızı morfolojiye sahip lifler, MHC-2a/ tip Ila; hızlı kasılan- oksidatif enzim aktivitesine sahip, kasılma hızı hızlı, beyaz morfolojiye sahip lifler ve MHC-2x / tip IIx (b) ; hızlı kasılan- glikolitik enzim aktivitesine sahip, kasılma hızı hızlı, beyaz morfolojiye sahip liflerdir. Hızlıdan yavaşa ve yavaştan hızlı kasılan kaslara dönüşen yapılardan elde edilen veriler MHC izoformlarıyla tersine çevrilebilir geçişlerin olduğu gösterilmiştir: MHC IIb <-> MHC IId/x <-> MHC Ila <-> MHC I. Buna göre, MHC izoformlarının yukarı ve aşağı regülasyonunu kapsayan kas lifi tipi geçişleri aşamalı bir şekilde gerçekleştiği tespit edildi (D. Pette ve Staron, 2000).

Kaslardaki liflerin tiplemesi için kullanılan miyozin ağır zinciri (MHC) immunohistokimyası kaslardaki liflerin tiplemesi için kullanılmakta olup ve MHC coekspresiyonu, iskelet kası plastisitesinin bir göstergesi olarak tanımlanır (Snow ve ark., 2005). Sarkopeniye bağlı iskelet kası kütlesi kaybına, toplam miyofiber sayısısındaki azalma, hızıı kasılan miyozin ağır zincir (MHC) Ila liflerinin boyutunun azalması ve değişen MHC morfolojisi aracılık etmektedir. Ortalama 70 yaşlarında olan kadınlar arasında yapılan çalışmaya göre; 12 haftalık aerobik egzersiz antrenmanından sonra; MHC I mRNA seviyesinin antrenman öncesine göre arttığı, MHC Ila protein oranının etkinlenmediği ve MHC Ilx protein seviyesi oranının ise azaldığı ve MHC I lif dağılımındaki artışın işe aerobik egzersiz eğitiminden sonra tüm kas gücündeki gelişme arasında bir ilişki varlığı tespit edilmiştir (Lüthi ve ark., 1986). 
Karip, B., ve Balcıoğlu, H.A. (2021). Egzersiz Fizyolojisi Bağlamında Musküler Plastisite. Gaziantep Üniversitesi Spor Bilimleri Dergisi, 6(3), 266-278.

Genç ve yaşlı yüzücüler, koşucular, vücut geliştirme eğitimi almış ve hareketsiz (aktif spor yapmayan) bireylerden alınan $\mathrm{m}$. vastus lateralis biyopsilerinin incelenmesine göre; genç yetişkinlere kıyasla hareketsiz yaşlı erişkinlerde daha yüksek miyozin ağır zincir tip I ve yavaş miyozin ağır zincir tip II içeriği rapor edilmiştir (Urso ve ark., 2005).

\section{Musküler plastisitenin egzersiz fizyolojisindeki yeri}

Düşük yük- dayanıklılık egzersizlerinin, kas dokusunda oksijen temini ve yıkımı ile ilgili spesifik değişikliklere sebep olduğu ve yüksek-yük kuvvet egzersizlerinin ise kontraktil proteinlerin artmasıyla karakterize, kas Ifilerinin büyümesine yol açtığı bilinmektedir (Hans Hoppeler, 2016). İskelet kası kapillerindeki fonksiyonun tam olarak anlaşılması, egzersiz çeşidine bağlı gelişen iskelet kası plastisitesine anlamada önemli bir rol oynamaktadır (Poole ve ark., 2021). Kas dokusunun dış streslere karşı cevabı hızlı ve kapsamlı olabilir. Örneğin; kronik elektriksel uyarı ile tavşanlara ait $\mathrm{m}$. tibialis anterior'da yüzeysel kısımlarında mitokondriyal içerikhareketliliğin 28 günde 7 kat arttığını bildiren bir çalışma bulunmaktadır (Reichmann, Hoppeler, Mathieu-Costello, von Bergen ve Pette, 1985). Insanlarda ise, m. vastus lateralis'te mitokondriyal içeriğin 6 haftalık dayanıklılık antrenmanlarıyla \%30 dan fazla artabildiğini; günlük antrenmanlarda, aynı gün içerisinde kas lifi boyutları ve kontraktil proteinlerin içeriklerinde yaklaşık \%10 luk bir artış olabildiğini gösteren çalışmalar vardır (Hoppeler, 1986; Lüthi ve ark., 1986). Tendonların elastik özellikleri kas kasılmasının kuvvetini, gücünü ve enerjisini etkiler ve içerisinde bulunan bağ dokusu matriksine ait elastiklikte mekanik destek sağlar (Lieber ve ark., 2017).

Yavaş ve hızlı kasılan kas liflerindeki genlerin diferansiyel ekspresyonları da lif aktivasyonuna bağlıdır. Görülen biyolojik olayların her ikisi de bu nedenle, Ca2++ 'a bağlı transkripsiyonel yollarla aşağı akışta kodu çözülen Ca2++ geçişinin genlik sinyali ve bu olayların süresiyle sıkı bir şekilde bağlantııdır. Eski çalışmalara göre; Ca2++'nın aktiviteye bağlı kas genliği ekspresyonunun düzenlemedeki rolü, kas plastisitesinde ve kas lifi tipi heterojenliğini açıklamada önemli olduğu kabul edilmektedir (Chin, 2004). Dinlenme koşulları altında, izole edilmiş tek kas liflerinde ölçülen hücre için serbest Ca2++ kontrasyonları 30-50 nM'dir. Bunun aksine kaslar kasılmak için aktive edildiğinde, yavaş motor ünitelerinin frekanslarında aktive olan yavaş kasılan (tip1) liflerde 100-300 nM'ye ulaştığı, hızlı motor ünitelerinin frekanslarında etkinleştirilen hızı kasılan (tip Ilb ve tip Ila) liflerde 1-2 mM'ye kadar 
Karip, B., ve Balcıŏlu, H.A. (2021). Egzersiz Fizyolojisi Bağlamında Musküler Plastisite. Gaziantep Üniversitesi Spor Bilimleri Dergisi, 6(3), 266-278.

yükselebildiği gösterilmiştir (Chin, 2005). Yer çekiminin düşük olduğu, uçuşlar sonrası insan ve hayvanlarda kas lifi atrofisi paternlerinde farklılıklar bulundu. Ratlarda atrofinin büyük kısmı tip Ila ya göre tip I liflerde görülürken, insanlarda bu etkinin tam tersi olduğu görüldü. Bu farklılığın başlangıç kas lifi boyutlarıyla alakalı olabileceği saptandı (Fitts, Riley ve Widrick, 2000). Diğer yandan aktivite azalmasına bağlı iskelet kası atrofisinin etkilendiği kilit faktörler; başlangıç kas lifi içeriği, inaktive olunan zamanın uzunluğu, inaktivasyon boyunca var olan pozisyon ve kasların genel yapısı olarak sıralandı (Bruton, 2002). Koşu sırasında büyük ölçüde güvenilen diğer bacak kasları hakkında genellemeler yapmak için $\mathrm{m}$. gastrocnemius'tan fizyolojik uyarlamalar yapmak yaygın olarak kabul edilir. Biz dizi çalışma, farklı bacak kaslarının (ör. m. vastus lateralis, m. soleus ve m. gastrocnemius) kronik yük boşaltma, yaşlanma ve akut egzersize belirgin şekilde yanıt verdiğini göstermektedir (Luden ve ark., 2012). İskelet kası çeşitli değişikliklere (yük, aktivite, inervasyon değişikliği vs.) adapte olabilmek için her daim yeniden şekillenme durumundadır. Gözlemlenen benzersiz plastisite, kasın çevre koşullarına göre yapısal ve fonksiyonel özelliklerini var olduğu duruma göre değiştirebilmesine olanak tanır. Bu durumun özellikle kaslardan beklenen spesifik performansları en iyi hale getirebilen belirli fenotipik değişiklikleri içeren, sporculara uygulanan antrenman metodlarına göre ayarlanabilirliğinin yaygın olarak kabul gördüğü fark edildi. Antrenmana bağlı kas yapısal değişiklikleri için kas kasılmasının sayısı ve yükleme derecesi gibi durumların baskın uyaranlar olduğu gözlemlendi. Örneğin; vücut geliştiriciler, kas hipertrofisi ve güç üretme kapasitesinde bir artışa neden olan düşük yoğunluk, yüksek yük kasılmalarına sebep olabilecek antrenmanlar uygularken, maraton koşucuları, hipertrofiyle ilgili olmayan, ancak kas liflerinin fazla yorgunluğa dirençli bir fenotip almasına neden olan yüksek yoğunluk ve düşük yük kasılmalarına sebep olabilecek antrenmanlar gerçekleştirdiği ve genetik yatkınlıklar bir yana, antrenman çeşitlerindeki bu farklılıklar, iki farklı sporcu grubunun farklı fiziksel özelliklere sahip olmasına önemli oranda katkıda bulunduğu tespit edilmiştir (Gransee ve ark., 2012).

Kasların kullanılmaması, iskelet kası zayıflığı üzerindeki etkisinden dolayı özellikle önemlidir. İnme ile bağlantılı hemiparezi ve onunla ilişkili iskelet kası plastisitesini etkileyen spesifik faktörlerin daha fazla anlaşılması, bu zayıflığa binaen terapötik egzersiz için yapılan planlamanın özgünlüğünün geliştirilmesini sağlayabilir ve bu nedenle, inme sonrası iskelet kası plastisitesine ilişkin mevcut çalışmalar yalnızca inmenin kendisinden değil, yaşlanmanın da zorunlu değişikliklerinden ve 
Karip, B., ve Balcıŏlu, H.A. (2021). Egzersiz Fizyolojisi Bağlamında Musküler Plastisite. Gaziantep Üniversitesi Spor Bilimleri Dergisi, 6(3), 266-278.

felçle ilişkili olmayan kullanımdan da etkilenebileceği ön görülmüştür. İnsan inme çalışmalarının doğasında bulunan değişkenliğin rehberliğinde, hayvan çalışmaları yaş, inme sonrası zaman aralığı, kas örneği boyutu ve aktivite seviyeleri gibi çeşitli faktörlerin daha fazla kontrolüne izin verebilir. Çeşitli kemirgen çalışmaları inme sonrası, daha sonraki çalışmalar için temel sağlaması açısından iskelet kası adaptasyonu ya da plastisitesi üzerinde uygulandı. Ratlarda oluşturulan inme modelinin akabinde takip eden 2 haftalık kontroller sonrası çok spesifik sonuçlar elde edilememiş olsada, çalışmalar sonucunda varılan sonuç: m. soleus kaslarında kontrol grubuna göre bilateral olarak tip 1 liflerde atrofi gözlemlenmiş olup, Tip 2 liflerde ise ipsilateral olarak gözlemlenmiştir. Fakat kas lifi tiplerinin oranlarında sağ ve sol taraflarda belirgin bir farklılık izlenmemiştir. Gözlemlenen bu atrofinin oluşmasının muhtemel sebepleri kas denervasyonu ve fiziksel aktivite azalmasıdır. Bu tarz çalışmalarda genellikle $\mathrm{m}$. soleus ve $\mathrm{m}$. tibialis anterior seçilmesinin sebebi $\mathrm{m}$. tibialis anterior 'un zayıflığı insanlardaki inme sonrası tipik bir motor eksikliği belirtisi olduğu bilinmesidir. Aynı zamanda bu kas m. soleus ile agonist/antagonist olarak çalışır. Araştırmaların, modellemelerden 2 hafta sonra yapılması birincil nörojenik süreç adaptasyonunun gerçekleşmesinden dolayıdır. Bu özelliğin, inme sonrası iskelet kası plastisitesinin doğal seyrini daha fazla incelemek için bir temel sağladığı saptanmıştır (Snow ve ark., 2012). Diğer bir çalışmaya göre, medulla spinalis yaralanmasını takiben 11 hafta sonunda rat ve insanlardan alınan $\mathrm{m}$. vastus lateralis biyopsisinin incelenmesiyle ortaya çıkan sonuçlara bakıldığında; kontrol grubunda, insanlarda ortalama lif boyutu ratlara göre \%63 daha büyük olduğu görülmüştür. Bu farkın büyüklüğü, insan liflerinin \%131 daha büyük olmasıyla en çok tip Ila liflerinde çarpıcıydı. Ratlarda tip I lifleri yoktu ve göreceli olarak tip Ilb/x lifleri daha yüksekti. Bu durum insan fenotiplerinin yapısından büyük ölçüden farklıydı. Medulla spinalis yaralanmasından sonra ise, hızlı kasılan fiberlerin alt tiplerinin oranında belirgin bir kayma oldu (daha önce Ila da olan artış Ilb/x yönünde ivlemelendi) ve insanlarda tip $\mathrm{Ilb} / \mathrm{x}$ liflerinin oranındaki \%77'lik artışın, rat'lar için kaydedilen \% 14'lük artışın 5 katı olduğu gözlemlenmiştir (Gregory ve ark., 2003).

\section{Musküler plastisite ile ilgili bazı genetik faktörler}


Karip, B., ve Balcıoğlu, H.A. (2021). Egzersiz Fizyolojisi Bağlamında Musküler Plastisite. Gaziantep Üniversitesi Spor Bilimleri Dergisi, 6(3), 266-278.

Egzersize karşı oluşan kas adaptasyonlarının yaşa göre değişiminin sebeplerinden biri de transkripsiyonel yanıtın zamanla değişebilir olmasındandır. İskelet kaslarında egzersiz ile artan metabolik aktivite, transkripsiyonel faktörlerde aktivasyon artışı olarak yansımaktadır (Endo ve ark., 2021). PGC-1a ( peroxisomeproliferator-activated receptor gamma, coactivator 1) geni , dayanıklılık antrenmanları ile kas dokusunda aktive edilen sinyalleme yolaklarının akış yönü elamanlarının kilit molekülüdür (Chan ve Arany, 2014). Aynı zamanda bu genin yüksek enerji taleplerine adaptasyon için aktive gen programındaki komponentler tarafından kontrol edildiği, çok çeşitli dokulardaki kapillerite ve mitokontriyal biogenesisi regüle eden transkripsiyonel co-activatörler (PGC-1 $\alpha, P G C-1 \beta$ and PGC-1) ailesinin bir üyesi olduğu ve çok sayıda transkripsiyon faktörü ile koordineli gen ekspresyon programları için ana düzenleyici olarak hizmet ederek enerji metabolizmasının kontrolünde rolü olduğu belirtilmektedir. PGC-1a'nın spesifik varyantlarının, kas dokusu mitokondriyal içeriğini ve kapilleritesini arttıran çeşitli fizyolojik durumlar tarafından indüklendiği izlenmiştir (Hans Hoppeler, 2016; Martínez-Redondo ve ark., 2015). Diğer yandan kas egzersizinin, reaktif oksijen türlerini (ROS) arttırdığı ve kasılan kasın nitrik oksit (NO) ve reaktif nitrojen türleri (RNS) 'nin de kaynağı olduğu da tespit edilmiştir (Balon ve Nadler, 1994). Kas egzersizi ürünü olan ROS ve RNS'lerin kas liflerine zarar verdiğine inanılıyordu ve bu inanışın spor içeceklerinde yaygın antioksidan kullanımına yol açması, sporcuların yüksek miktar kimyasal komponentlere maruz kalmasına sebep oldu. Son 15 yılda, ROS ve RNS'si egzersiz ve immobilite ile iskelet kası plastisitesinde önemli bir rol oynadığı kabul edildi ve bu yapıların öngörüldüğü gibi zararlı olmadığı kanıtlandı (Hans Hoppeler, 2016). Fakat buna rağmen sporcu içeceklerinde halen kullanılmaya devam eden antioksidanların seviyelerinin hangi bilimsel temeller üzerine ayarlandığı her yönüyle bilinmemektedir.

Kasların kendini onarma kabiliyetini sağladığı düşünülen uydu hücrelerinin, yüksek mitotik kapasiteye sahip olduğu ve yetişkinlerdeki iskelet kaslarının korunmasına ve yenilenmesine katkıda bulundupu gözlemlendi. Yaralanma sonrası aktive olan miyojenik uydu hücreleri, miyoblast diferansiyasyon (MYOD) ve/veya miyojenik faktör 5 (MYF5) gibi miyogenezin düzenleyici faktörlerinin ekspresyonlarını başlatır. İskelet kası rejenerasyon kapasitesini geliştirmek için diet yöntemlerindeki değişikliklerin, rejeneratif süreci hızlandırmak ve yaralanma sonrası oluşan geniş fibrotik alanları azaltabilmek için güçlü bir aracı olabileceği görüldü (Abreu ve ark., 2017). Direnç egzersiziyle ortaya çıkan mekanik uyarım kaynaklı meydana gelen 
Karip, B., ve Balcıoğlu, H.A. (2021). Egzersiz Fizyolojisi Bağlamında Musküler Plastisite. Gaziantep Üniversitesi Spor Bilimleri Dergisi, 6(3), 266-278.

iskelet kası hipertrofisiyle mTORC1 (mammalian target of rapamycin complex 1) aktivasyonunun bağlantısı bulunmaktadır (Khodabukus, 2021). Diet ile ilgili araştırmalar, zeytinyağında bulunan oleik asit ve asit, mısır yağı gibi maddelerin içerisinde bulunan linoleik asitin vasküler düz kas üzerinde proliferatif etkilere neden olduğunu, kas büyümesini düzenleyebileceğini ve kas diferansiyasyonu sırasındaki total fosfolipid içeriğini arttığını göstermiştir (Kelley ve ark., 2006).

İnsan ve hayvan çalışmaları IGF-1 ( Insulin-like growth factor-I) 'in iskelet kası büyümesi için önemli bir düzenleyici olduğunu öne sürmektedir. İnsan çalışmaları, IGF-1'in iskelet kası ve serum konsantrasyonlarının yetişkinlerde yaş ilerledikçe daha olduğu rapor edildi. IGF-1 ile ilgili yapılan çalışmalarda, yaşlılarda, yaklaşık 10 haftalık bir direnç antrenman programından sonra Z band'ı hasarının artığı görüldü (Urso ve ark., 2005). Son çalışmalar, "angiotensin converting enzim" in genotipinin bazı çelişkili sonuçlara rağmen, fiziksel performansa etkisi olduğunu keşfetti. Anjiotensin dönüştürücü enzim inhibitörü ilaçlar, genellikler kardiyak disfonksiyon için tanınmış terapilerde reçete edilir. Etkilerinin iskelet ve kalp kasının metabolik performansını iyileştirmesi mümkün olabileceği gözlemlendi (Montgomery ve Brull, 2000). IGF-1 reseptörü, direkt iskelet kası gücü ve kütlesini etkileyen endojen IGF-1 sisteminin yaşla ilgili regülasyon azalmasında dominant rol oynar (Urso ve ark., 2005). Bu reseptörün iskelet kası plastisitesine olan etkili ile ilgili çalışmaların az oluşu, yaşılıardaki mobilizasyon sorununa ışık tutabilecek internal ve eksternal sebeplerin tam anlaşılmasını zorlaştırmaktadır. Ek olarak FOXO transkripsiyon faktörlerinin iskelet kası homeostasisinde çeşitli fonksiyonlara sahip olduğu ve özellikle intrasellüler proteinlerin azalmasından sorumlu iki ana mekanizmanın birkaç componentlerinin transkripsiyonunu ve disfonksiyonel organellerinin, ubiquitinprotasome kompleksinin ve otofaji-lizozom yollarının eliminasyonunu regüle ettiği gözlemlendi (Sanchez ve ark., 2014). Ve respiratuar kasların da temel yapı ve fonksiyonlarının diğer iskelet kaslarından farklı olmadığı ve respiratuar kaslara kıyasla yaklaşık \%40'lık oranıyla iskelet kaslarının insan vücudunda bulunan en büyük doku kütlesi olduğu tespit edilmiştir (Gransee ve ark., 2012).

\section{Tartışma ve Sonuç}

Kas liflerinde yük seviyesi, egzersiz çeşidi ve aktivasyon süresine göre çeşitli makro ve mikro düzeyde değişikliklerin görülmesine bağlı olarak planlanacak her türlü antrenman çeşidi kendine özgü olmalıdır. Dayanıkııık ve kuvvet antrenmanları 
Karip, B., ve Balcıoğlu, H.A. (2021). Egzersiz Fizyolojisi Bağlamında Musküler Plastisite. Gaziantep Üniversitesi Spor Bilimleri Dergisi, 6(3), 266-278.

gibi fiziksel egzersiz çeşitleri, metabolik değişikliklere yol açan ve bunların etkisiyle ortaya çıkan morfolojik değişiklikler için önemli bir stres türüdür. Ek olarak egzersizlerin etki ettiği kasların fenotipinde, egzersiz çeşitlerinin yanında diğer bir önemli faktör ise kası inerve eden motor sinirdir. Sinir-kas ilişkisini ortaya koyan ve en yaygın olarak kullanılan testler, inme modellemeli olanlardır. İnme sonrası gelişen denervasyonun neden olduğu atrofi kas plastisitesi'nin negatif yönlü seyrini izlemek için uygun bir örnektir.

İnsanlarda bulunan 3 adet MHC isoformunun yavaş ve hızlı kasılan tiplerinin birbirlerine dönüşebilir olduğu da gösterilmiştir. Aynı zamanda MHC'ler kas lifi tiplemesinde kullanıldığından, musküler plastisite kavramı tanımlamasındaki en önemli yapıdır. Gelişimsel veya edinilmiş hastalıklar sonucunda görülen plastisitenin, hangi MHC isoformu'nun etkilendiğine göre değişmesi buna en iyi kanıtlardan biridir.

Genel olarak bakıldığında iskelet kası plastisitesine etki eden en önemli faktörler; fiziksel egzersiz çeşidi ve içeriği, hastalıklar, yaşam tarzı (yüksek rakımlı yerler vs.), yaş ve tüm bu faktörlerin ortak olarak etkilediği MHC isoformlarındaki değişikliklerdir.

\section{Kaynaklar}

Abreu, P., Leal-Cardoso, J. H., Ceccatto, V. M., \& Hirabara, S. M. (2017). Regulation of muscle plasticity and trophism by fatty acids: A short review. Rev Assoc Med Bras (1992), 63(2), 148-155.

Baldwin, K. M. (2000). Research in the exercise sciences: where do we go from here? J Appl Physiol (1985), 88(1), 332-336.

Balon, T. W., \& Nadler, J. L. (1994). Nitric oxide release is present from incubated skeletal muscle preparations. J Appl Physiol (1985), 77(6), 2519-2521.

Bishop, D. J., Granata, C., \& Eynon, N. (2014). Can we optimise the exercise training prescription to maximise improvements in mitochondria function and content? Biochim Biophys Acta, 1840(4), 1266-1275.

Bruton, A. (2002). Muscle Plasticity: Response to training and detraining. Physiotherapy, 88(7), 398-408.

Chan, M. C., \& Arany, Z. (2014). The many roles of PGC-1a in muscle - recent developments. Metabolism, 63(4), 441-451. 
Karip, B., ve Balcığlu, H.A. (2021). Egzersiz Fizyolojisi Bağlamında Musküler Plastisite. Gaziantep Üniversitesi Spor Bilimleri Dergisi, 6(3), 266-278.

Chin, E. R. (2004). The role of calcium and calcium/calmodulin-dependent kinases in skeletal muscle plasticity and mitochondrial biogenesis. Proc Nutr Soc, 63(2), 279-286.

Chin, E. R. (2005). Role of Ca2+/calmodulin-dependent kinases in skeletal muscle plasticity. J Appl Physiol (1985), 99(2), 414-423.

Eccles, J. C. (1958). Problems of plasticity and organization at simplest levels of mammalian central nervous system. Perspect Biol Med, 1(4), 379-396.

Endo, Y., Zhang, Y., Olumi, S., Karvar, M., Argawal, S., Neppl, R. L., \& Sinha, I. (2021). Exercise-induced gene expression changes in skeletal muscle of old mice. Genomics, 113(5), 2965-2976.

Fitts, R. H., Riley, D. R., \& Widrick, J. J. (2000). Physiology of a microgravity environment invited review: microgravity and skeletal muscle. J Appl Physiol (1985), 89(2), 823-839.

Gransee, H. M., Mantilla, C. B., \& Sieck, G. C. (2012). Respiratory muscle plasticity. Compr Physiol, 2(2), 1441-1462.

Gregory, C. M., Vandenborne, K., Castro, M. J., \& Dudley, G. A. (2003). Human and rat skeletal muscle adaptations to spinal cord injury. Can J Appl Physiol, 28(3), 491-500

Hall, J. E., \& Hall, M. E. (2020). Guyton and Hall Textbook of Medical Physiology (14th ed.): Elsevier.

Hoppeler, H. (1986). Exercise-induced ultrastructural changes in skeletal muscle. Int J Sports Med, 7(4), 187-204.

Hoppeler, H. (2016). Molecular networks in skeletal muscle plasticity. 219(2), 205213.

Kelley, D. S., Bartolini, G. L., Newman, J. W., Vemuri, M., \& Mackey, B. E. (2006). Fatty acid composition of liver, adipose tissue, spleen, and heart of mice fed diets containing t10, c12-, and c9, t11-conjugated linoleic acid. Prostaglandins Leukot Essent Fatty Acids, 74(5), 331-338.

Khodabukus, A. (2021). Tissue-Engineered Skeletal Muscle Models to Study Muscle Function, Plasticity, and Disease. Front Physiol, 12, 619710.

Lieber, R. L., Roberts, T. J., Blemker, S. S., Lee, S. S. M., \& Herzog, W. (2017). Skeletal muscle mechanics, energetics and plasticity. J Neuroeng Rehabil, 14(1), 108. 
Karip, B., ve Balcığlu, H.A. (2021). Egzersiz Fizyolojisi Bağlamında Musküler Plastisite. Gaziantep Üniversitesi Spor Bilimleri Dergisi, 6(3), 266-278.

Luden, N., Hayes, E., Minchev, K., Louis, E., Raue, U., Conley, T., \& Trappe, S. (2012). Skeletal muscle plasticity with marathon training in novice runners. 22(5), 662-670.

Lüthi, J. M., Howald, H., Claassen, H., Rösler, K., Vock, P., \& Hoppeler, H. (1986). Structural changes in skeletal muscle tissue with heavy-resistance exercise. Int J Sports Med, 7(3), 123-127.

Martínez-Redondo, V., Pettersson, A. T., \& Ruas, J. L. (2015). The hitchhiker's guide to PGC-1a isoform structure and biological functions. Diabetologia, 58(9), 1969-1977.

Montgomery, H., \& Brull, D. (2000). Gene-environment interactions and the response to exercise. Int J Exp Pathol, 81(5), 283-287.

Pette, D. (2001). Historical Perspectives: Plasticity of mammalian skeletal muscle. J Appl Physiol (1985), 90, 1119-1124.

Pette, D., \& Staron, R. S. (2000). Myosin isoforms, muscle fiber types, and transitions. Microsc Res Tech, 50(6), 500-509.

Poole, D. C., Kano, Y., Koga, S., \& Musch, T. I. (2021). August Krogh: Muscle capillary function and oxygen delivery. Comparative Biochemistry and Physiology Part A: Molecular \& Integrative Physiology, 253, 110852.

Reichmann, H., Hoppeler, H., Mathieu-Costello, O., von Bergen, F., \& Pette, D. (1985). Biochemical and ultrastructural changes of skeletal muscle mitochondria after chronic electrical stimulation in rabbits. Pflügers Archiv, 404(1), 1-9.

Sanchez, A. M., Bernardi, H., Py, G., \& Candau, R. B. (2014). Autophagy is essential to support skeletal muscle plasticity in response to endurance exercise. Am J Physiol Regul Integr Comp Physiol, 307(8), R956-969.

Snow, L. M., Low, W. C., \& Thompson, L. V. (2012). Skeletal muscle plasticity after hemorrhagic stroke in rats: influence of spontaneous physical activity. $A m \mathrm{~J}$ Phys Med Rehabil, 91(11), 965-976.

Snow, L. M., Sanchez, O. A., McLoon, L. K., Serfass, R. C., \& Thompson, L. V. (2005). Myosin heavy chain isoform immunolabelling in diabetic rats with peripheral neuropathy. Acta Histochem, 107(3), 221-229.

Standring, S. (2015). Gray's Anatomy- The Anatomical Basis of Clinical Practice (S. Standring Ed. 41th ed.): Elsevier. 
Karip, B., ve Balcıŏlu, H.A. (2021). Egzersiz Fizyolojisi Bağlamında Musküler Plastisite. Gaziantep Üniversitesi Spor Bilimleri Dergisi, 6(3), 266-278.

Tesch, P. A. (1988). Skeletal muscle adaptations consequent to long-term heavy resistance exercise. Med Sci Sports Exerc, 20(5 Suppl), S132-134.

Urso, M. L., Fiatarone Singh, M. A., Ding, W., Evans, W. J., Cosmas, A. C., \& Manfredi, T. G. (2005). Exercise training effects on skeletal muscle plasticity and IGF-1 receptors in frail elders. Age (Dordr), 27(2), 117-125.

Vickers, P. S., Nair, M., Wheeldon, A., Peate, I., \& Migliozzi, J. G.(2011). Fundamentals of Anatomy and Physiology. For Nursing and Healthcare Students. Ringgold, Inc, Portland. 